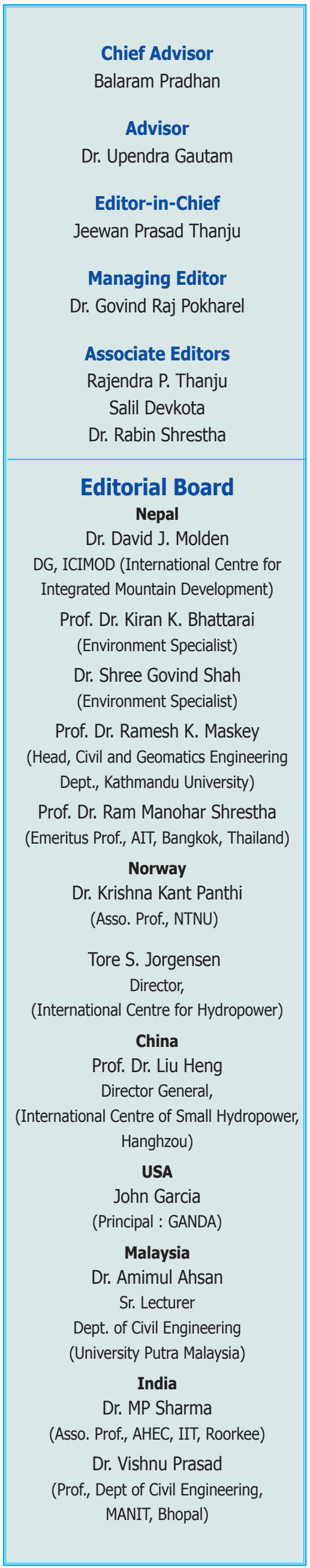

\title{
Harnessing Water for Greater Regional Good
}

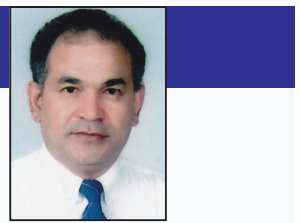

$\mathbf{S}^{\text {s }}$ can complement one another in the harnessing of natural resources. For example, Nepal's hydropower may be exported to the Republic of India and beyond. Similarly, electricity from thermal may be imported in dry season from India. Nepal in return can improve its transit and trade regime. But more important is water. Due to increasing population and requirement for increased food production, and industrial output, water demand in the region is increasing while the traditional reliability of water availability will be decreasing due to climate change.

The monsoon in the climate shifting scenario creates both devastating floods and drought; and there is uncertainty in seasonal water availability. Storage projects, as a proven technology with good environmental foresight, will help regulate the flows and minimize the misery due to high floods and drought. Such regulated flows are invaluable for protecting life and property of the people, assuring water and food security. The already most populated as it is, the demand for water in the Republic of India for its food security, clean energy demand and many other needs are going to be the most challenging task for the country in the days ahead. Appropriately designed multipurpose storage projects in Nepal could be the suitable way to meet these challenges downstream in India provided these projects can be based on the principles of equitable benefits sharing between the countries. This can be a win - win gain for both the countries. We are confident that the people of Nepal are even willing and ready to go to face some hardship to be created by such projects.

Water will always remain the most feasible source of clean energy. Hence, in the interest of South Asian countries, it will be fruitful to practice mutual cooperation for harnessing this resource. The first concrete step in this direction may be building of confidence between Nepal and India. The deep rooted misgiving, ingrained since the history of the Koshi River, Gandak River and Mahakali River bilateral agreements, that Nepal gets a raw deal in any water resources deal with India, needs to be cleared away. As the biggest country in the South Asia region, the onus falls on India to be more accountable towards the neighboring countries. Greater South Asian regional partner China, that is South Asia+China, can also help in the process with investment, technology, water conservation practices and the natural link it has with the majority of South Asian countries through its rivers and mountains.

In this context, there is no point talking about any new water project. The Pancheshwor Multipurpose Project on Mahakali River was considered to generate 6,720 MW of electricity and 6.56 billion cu $\mathrm{m}$ of live storage behind the $315 \mathrm{~m}$ high dam. There is no substantive progress even after 16 years the two countries having signed the project.

Western sources repeatedly state that India is poised to become a Global Player/Power in the coming decade or so. But the recent sudden, massive and prolonged power failure in North India indicates the quality and efficiency of such assertions. In summary, it is imperative to realize and utilize the natural resources of the neighboring countries, beyond their boundary for mutual benefit by overcoming such mistrust. And no doubt, this is historically a very challenging task.

Now talking about something different. We would like to thank Executive Editor, Dr. Don Messerschmidt, for his long service in editing the HN journal for last 11 issues. His services were outstanding, and were instrumental in getting this journal the India Power Award-2009 in international category. Now, Dr. Messerschmidt has left the HN team due to his other engagements. We wish him every success in his career and his personal life.

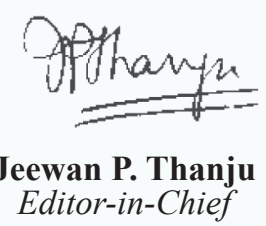

